\title{
Antibacterial Activity of Ciprofloxacin-Encapsulated Cockle Shells Calcium Carbonate (Aragonite) Nanoparticles and Its Biocompatability in Macrophage J774A.1
}

\author{
Tijani Isa ${ }^{1,2}$, Zuki Abu Bakar Zakaria ${ }^{1,3}, *$, Yaya Rukayadi ${ }^{2}$, Mohd Noor Mohd Hezmee ${ }^{4}$, \\ Alhaji Zubair Jaji ${ }^{3}$, Mustapha Umar Imam ${ }^{1}$, Nahidah Ibrahim Hammadi ${ }^{3}$ and \\ Saffanah Khuder Mahmood ${ }^{3}$ \\ 1 Laboratory of Molecular Biomedicine, Institute of Bioscience, Universiti Putra Malaysia, Serdang, \\ Selangor 43400, Malaysia; tjelyakub@gmail.com (T.I.); mustyimam@gmail.com (M.U.I.) \\ 2 Faculty of Food Science and Technology and Laboratory of Natural Product, Institute of Bioscience, \\ Universiti Putra Malaysia, Serdang, Selangor 43400, Malaysia; yaya_rukayadi@upm.edu.my \\ 3 Faculty of Veterinary Medicine, Universiti Putra Malaysia, Serdang, Selangor 43400, Malaysia; \\ jajidvm@yahoo.com (A.Z.J.); naheda_ibrahem@yahoo.com (N.I.H.); saffanh.jeber@gmail.com (S.K.M.) \\ 4 Laboratory of Pharmacology and Toxicology, Faculty of Veterinary Medicine, Universiti Putra Malaysia, \\ Serdang, Selangor 43400, Malaysia; hezmee@upm.edu.my \\ * Correspondence: zuki@upm.edu.my; Tel.: +603-89-462-102; Fax: +603-89-472-101
}

Academic Editor: Már Másson

Received: 12 January 2016; Accepted: 19 April 2016; Published: 19 May 2016

\begin{abstract}
The use of nanoparticle delivery systems to enhance intracellular penetration of antibiotics and their retention time is becoming popular. The challenge, however, is that the interaction of nanoparticles with biological systems at the cellular level must be established prior to biomedical applications. Ciprofloxacin-cockle shells-derived calcium carbonate (aragonite) nanoparticles (C-CSCCAN) were developed and characterized. Antibacterial activity was determined using a modified disc diffusion protocol on Salmonella Typhimurium (S. Typhimurium). Biocompatibilittes with macrophage were evaluated using the 3-(4,5-Dimethylthiazol-2-yl)-2,5-diphenyltetrazolium bromide (MTT) and 5-Bromo-2'-deoxyuridine (BrdU) assays. Transcriptional regulation of interleukin 1 beta (IL-1 $\beta$ ) was determined using reverse transcriptase-polymerase chain reaction (RT-PCR). C-CSCCAN were spherical in shape, with particle sizes ranging from 11.93 to $22.12 \mathrm{~nm}$. Encapsulation efficiency (EE) and loading content (LC) were $99.5 \%$ and $5.9 \%$, respectively, with negative $\zeta$ potential. X-ray diffraction patterns revealed strong crystallizations and purity in the formulations. The mean diameter of inhibition zone was $18.6 \pm 0.5 \mathrm{~mm}$, which was better than ciprofloxacin alone $(11.7 \pm 0.9 \mathrm{~mm})$. Study of biocompatability established the cytocompatability of the delivery system without upregulation of IL-1 $\beta$. The results indicated that ciprofloxacin-nanoparticles enhanced the antibacterial efficacy of the antibiotic, and could act as a suitable delivery system against intracellular infections.
\end{abstract}

Keywords: antimicrobial resistance; calcium carbonate (aragonite) nanoparticles; ciprofloxacin; intracellular infection; proinflammatory cytokine

\section{Introduction}

Antimicrobial resistance is a growing problem [1]. The emergence of intracellular bacterial infections and acquired resistance of pathogenic microbes pose significant challenges for many antimicrobial agents [2]. Since the 1980s, flouroquinolones have been used in clinical practice [3], and they have contributed to major advances in the medical treatment of gram negative bacterial 
infections as frontline drugs [2]. Active efflux from prokaryotes as well as eukaryotic cells strongly modulates the activity of this class of antibiotics [4-6]. Thus, the intracellular actions of flouroquinolones are often sub-optimal [7] due to continued efflux [5,6]. This contributes to failure of conventional fluoroquinolones therapies as a result of decreased accumulation and poor retention of the antibiotics inside the cells $[8,9]$. Other factors limiting the success and clinical use of fluoroquinolones like ciprofloxacin include their bitter taste in solution, and rapid renal clearance, in which a minimum of $70 \%$ of the oral dose is excreted unchanged in the urine. Moreover, frequent administration of ciprofloxacin is associated with numerous side-effects [10-12]. In order to achieve successful treatment, antibiotics must fulfill a series of criteria, including the ability to penetrate and be retained by the cell, the capacity to reach the intracellular target, and the display of activity against bacteria residing in the intracellular environment [13]. On the other hand, due to the deficiency in new antibacterial agents, there is considerable interest in restoring the activity of older and conventional antimicrobials [14].

The use of safe and efficient delivery systems, capable of delivering therapeutic agents in an adequate concentration within the appropriate intracellular compartment is an ultimate goal in enhancing therapeutic effect. It is also a promising strategy in overcoming microbial resistance $[15,16]$. The encapsulation of antibiotics in carriers could avoid antibiotic efflux and enhance the drugs' intracellular retention, since delivery systems like nanoparticles are not substrates of the efflux pump proteins [17]. Moreover, encapsulation of antibiotics improves their pharmacokinetics by increasing serum half-life [2]. Nanoparticles can be phagocytose by host phagocytes containing intracellular microbes. Once inside host phagocytes, the antibiotic-nanoparticle delivery system could release high dose of the antibiotic to eliminate the intracellular microbes before developing resistance [18-20].

Many studies have reported the increased antimicrobial activity of ciprofloxacin conjugated nanoparticles [21-23]. Likewise, decreased antibiotic resistance and increase antibacterial activity of ciprofloxacin was reported in the presence of Zinc Oxide nanoparticles [24]. It is anticipated that the use of nanoparticles-based drug delivery systems will continue to improve treatment of bacterial infections and multidrug-resistant microbes [19]. However, no studies have been conducted on the potential of ciprofloxacin encapsulated cockle shells-calcium carbonate (aragonite) nanoparticles (CSCCAN), to enhance the efficacy of the drug. The cockle shells (Anadara granosa), which is available in abundance, is often considered a waste and it is a cheap protein source [25]. Moreover, calcium carbonate has been used for controlled delivery of biomolecules due to it biodegradability, biocompatibility, porous nature and simple bulk-scale preparation [26,27]. A porous aragonite calcium carbonate nanoparticles loaded with gentamicin sulfate with controlled released property have been successfully used in osteomyelitis treatment [28]. Thus, calcium carbonate nanoparticles are expected to also enhance the efficacy of ciprofloxacin.

The continuous assembly of engineered nanoparticles as drug carrier system necessitates a comprehensive understanding of their potential toxicity [29]. Despite many reports on the toxicity of nanomaterials, the precise association between engineered nanoparticles and the immune system have not been broadly studied [29-31]. Macrophages are the key players in the innate immune response that phagocytose large foreign particles or endocytose biological molecules and tiny materials. Furthermore, engulfment of foreign materials renders macrophages more activated to complete the task of instigating and inducing the adaptive immune responses by discharging a variety of pro-inflammatory cytokine [32]. A critical indicator of nanoparticles toxicity is its ability to provoke an unwanted immune response in a biological system. Additionally, understanding the biological response to nanoparticles at the sub cellular level is crucial and can present further evidence on the interaction between nanomaterials and cells. It is thus essential to understand the immunogenic potential of the CSCCAN with respect to pro-inflammatory protein production. 


\section{Results and Discussion}

\subsection{Preparation of Nanoparticles}

The nanoparticles were synthesized in an optimized experiment via a microemulsion system using a high pressure homogenizer $(\mathrm{HPH})$. Microemulsion system is recognized as the most ideal medium for the preparation of inorganic crystal particles [33]. In this study, the nanoparticles were successfully produced from a suspension of pore structured micron-sized cockle shells-calcium carbonate powder (CSCCP) (Figure 1a). As revealed by the Transmission Electron Microscopy (TEM) micrograph (Figure 1b), spherical-shaped nanoparticles were obtained during the synthesis. The average particles size was found in the range of 11.93 to $22.12 \mathrm{~nm}$.

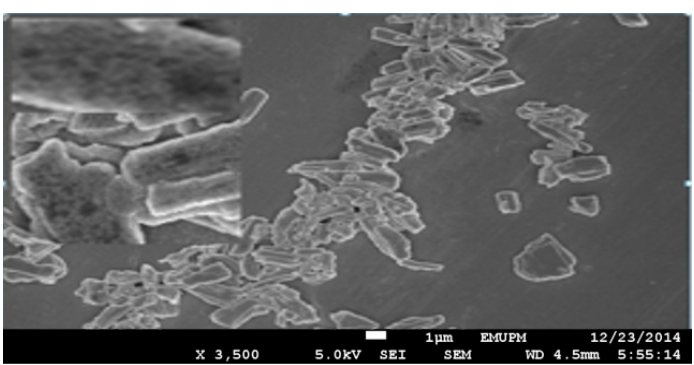

(a)

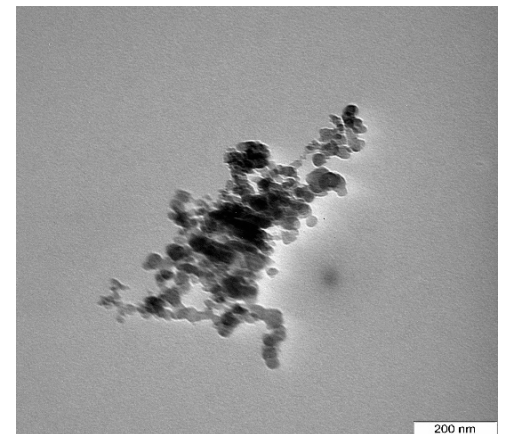

(b)

Figure 1. Field Emission Scanning Electron Microscope (FESEM) micrograph showing the pore structure of the micron-size cockle shells calcium carbonate powder, scale bar $=1 \mu \mathrm{m}$ (a); and Transmission Electron Microscopy (TEM) micrographs showing nanoscale spherical-shaped cockle shells calcium carbonate (aragonite) nanoparticles (b).

During the synthesis of inorganic $\mathrm{CaCO}_{3}$, the presence of chemical modifiers, temperature, supersaturation, and $\mathrm{pH}$ are essential growth controlling factors [34]. It is likely that the amount of surfactant and co-surfactant (Tween- 80 and glycerol) at the weight/volume ratio of 2:1 aided in the formation of the homogenous, nano-sized particles. Using Tween-80, Zou and coworkers (2009), synthesized homogenous nanoparticles with a smaller particle size and without aggregation, which was attributed to the superior emulsifying capacity of the surfactant [35].

Homogenizer is a proficient machine for the reduction of particle and droplet sizes [27]. The impact of high turbulence and shear force, coupled with compression and acceleration caused the breakdown of particles and dispersion throughout the sample [36]. After a 25-cycle homogenization process, the particles were evenly distributed in size, probably due to the number of cycles, and the operating pressure. Therefore, it is suggested that nanoparticles size and morphological structure can be controlled by adjusting the reaction medium and homogenization time.

\subsection{Ciprofloxacin-Loading and Encapsulation Efficiency}

The nanoparticles loading of drug is commonly accepted as the sum total amount of bounded drug per polymer mass [37]. The C-CSCCAN was successfully prepared in drug: nanoparticles ratio (1:17). The percentage LC of ciprofloxacin in the formulations was approximately $5.9 \%$ and the encapsulation efficiency (EE) was $99.5 \%$ The loading of ciprofloxacin into capsule material was suggested as a function of feeding concentration [38]. With the increase in the feeding concentration of ciprofloxacin, high loading capacity was observed. At a lower feeding concentration, the loading content became low. The small molecular size of ciprofloxacin [38], and the long overnight loading period was assumed to influence more loading. The increased loading capacity could also be induced by the porous nature of the nanoparticles (as shown in Figure 1a). 
Encapsulation of various biomolecules into the hollow cavity of capsules could be achieved by several methods [39-41]. However, the present method is effortless and effective. The semi-water-soluble ciprofloxacin was probably deposited in the interior of the nanoparticles in a concentration dependent manner upon simple mixing and overnight stirring. The higher percentage encapsulation efficiencies were obtained with increasing amount of ciprofloxacin. This demonstrated minimal loss of the drug during the loading process. The above finding was similar to the reports presented previously [42,43]. Comparing the effectiveness of preparation methods, Abreu et al. (2010) observed that particles produced in water-in-oil emulsion method presented relatively higher EE values [44].

\subsection{Characterization and Stability of Ciprofloxacin-Nanoparticles}

The comprehensive examination of physicochemical properties of nanoparticles is a prerequisite to full understanding of their potential application [45]. The micrograph images at lower magnification revealed the unaltered spherical shape of the nanoparticles (Figure 2) following the drug loading process. The particle sizes were between 13.94 and $23.95 \mathrm{~nm}$ and uniformly distributed. The particle sizes of nude nanoparticles (Figure 1b) were found to be the same as ciprofloxacin-encapsulated nanoparticles.

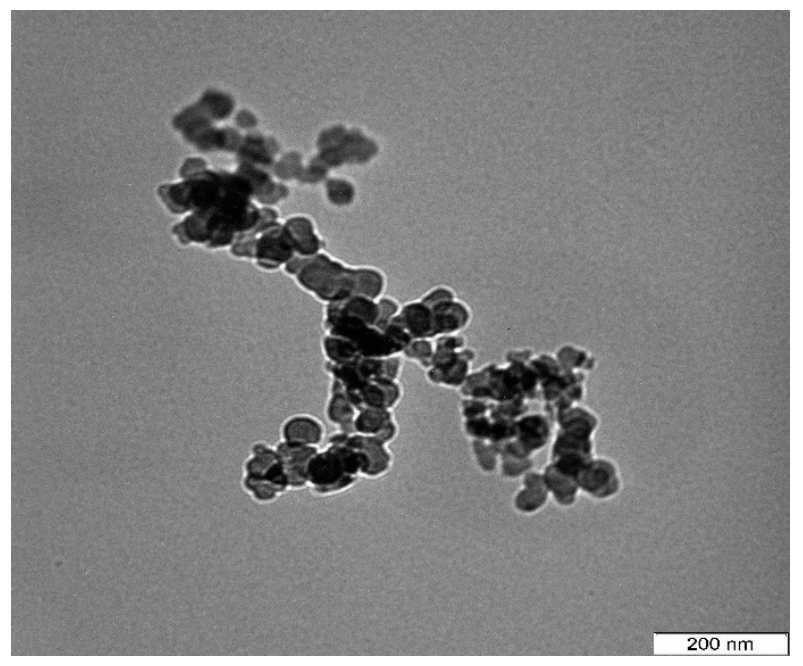

Figure 2. TEM micrograph of spherical shaped ciprofloxacin-encapsulated cockle shells calcium carbonate (aragonite) nanoparticles.

This result is in agreement with the observation of Mu and Feng (2003), who established that loading of drug into nanoparticles did not significantly affect the particle size [46]. However, it has been visibly demonstrated that size of nanoparticle is one of the most essential feature in influencing the activities of the complexes in vitro and in vivo [47], and it plays a significant role in the uptake by macrophages and passive penetration of the cell membrane [48,49]. Therefore, the reduced particle size obtained in this study was suggested to improve patient comfort.

The characteristic crystalline structure and purity of the samples were estimated using X-ray diffraction (Figure $3 \mathrm{a}-\mathrm{c}$ ). Strong crystallizations were observed in the formulation, as indicated in Figure $3 \mathrm{a}, \mathrm{b}$, corresponding to CSCCAN and C-CSCCAN, respectively. Broad sharp, crystal peaks were observed at diffraction angles of $2 \theta=26.2,27.3,33.1,38.7,38.8,46.1,48.3$, and 52.8 in all the samples.

The original crystal natures of CSCCP were not changed and did not disappear during preparation and when loaded with ciprofloxacin. Likewise, several sharp and clear X-ray Powder Diffraction (XRD) diffraction peaks attributable to ciprofloxacin could not be traced in the loaded nanoparticles, suggesting that the preparation process has no effect on the nanoparticles crystalline properties and 
the formulation is free from impurities. This observation was supported by an earlier finding [50]. Ciprofloxacin showed its specific crystal peaks around $2 \theta=14.1,21.1$, and 25.1. Likewise, several sharp and clear XRD diffraction peaks attributable to ciprofloxacin could not be traced in the loaded nanoparticles.

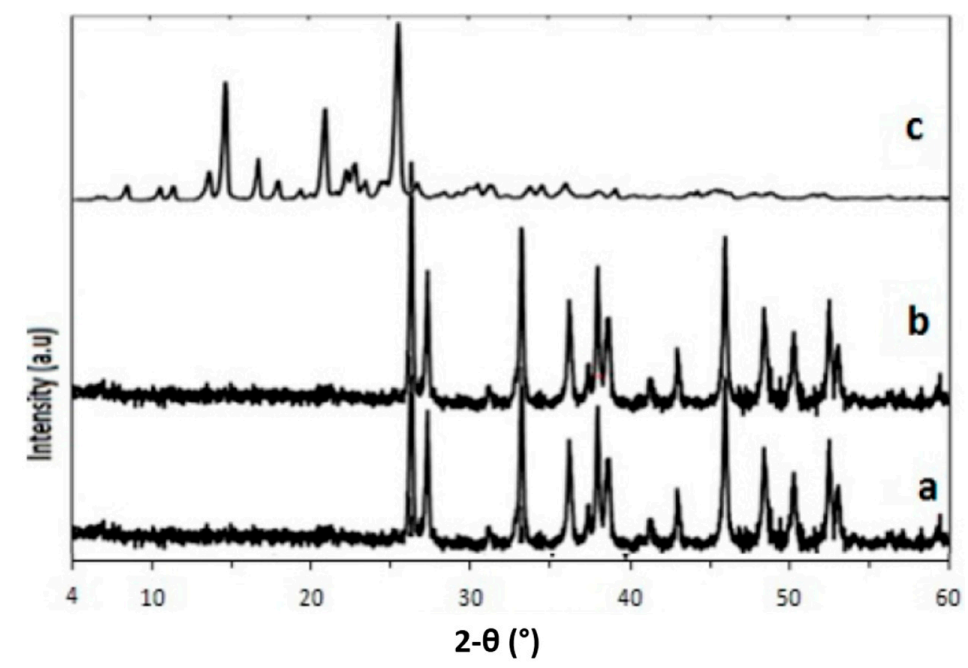

Figure 3. X-ray Powder Diffraction (XRD) spectra of cockle shells calcium carbonate (aragonite) nanoparticles (a); ciprofloxacin-encapsulated cockle shells calcium carbonate (aragonite) nanoparticles (b); and free ciprofloxacin (c) showing crystalline phases and purity.

The $\zeta$ potential is usually an indicator of the stability of colloidal dispersion, which measures shelf life, nanoparticle interaction with charged drugs in a dispersion, and also the bonding and electrostatic repulsion of drug delivery systems with biological system [51]. The $\zeta$ potentials of the formulations in pH 7.4 exhibited a slightly negative charge of $-15.3 \pm 2.0 \mathrm{mV}$ and $-13.0 \pm 1.9 \mathrm{mV}$ for the CSCCAN and C-CSCCAN, respectively. Evaluating the $\zeta$ potential values between the loaded nanoparticles and nude nanoparticles revealed that loading of the antibiotic slightly reduced the surface charge of the carrier. The differences in $\zeta$ potential may be due to physico-chemical properties of the drug. However, the strengths of the cationic drug like ciprofloxacin could be expected to influence formulations $\zeta$ potential only when the drug was present at the surface [52]. Since such an effect was not observed, nearly the sum total of the drug molecules was possibly incorporated into the inner core of the nanoparticles. The negative potential values indicate stability and electrostatic repulsion that protects the particles from aggregation to some extent, though Kanaujia and coworkers (2011) have stressed that higher negative or positive $\zeta$ potential prevents aggregation of the particles, due to electric repulsion and this electrically stabilizes the nanoparticles dispersion [53]. In both negatively and positively charged particles, experts have established that the degree of phagocytosis enhances with increasing $\zeta$ potential, and is low when $\zeta$ potential is zero [49]. Lu et al. (2007) stated that the half-life of encapsulated carrier might be increased in circulation when the carrier is negatively charged, since the surface charge of the endothelium is also negative [47]. Therefore, the optimal potential values obtained in the present study suggest the suitability of the nanoparticles for systemic drug delivery.

\subsection{Biocompatibility Evaluation}

\subsubsection{Immunogenicity Assessment}

Immunogenicity is the capability of a certain substance to provoke immune response in biological systems. Unwanted immune response to therapeutic agents may result in adverse events such as systemic inflammatory response [54,55]. Immunogenicity is influenced by multiple characteristics of an 
antigen including molecular size, chemical composition and degradability. Analyzing the interaction of nanoparticles with the body defense mechanisms is of particular relevance in the event of the particles employed for medical applications, as they are often injected into the blood stream and can be found in direct contact with a large number of immune cells [56].

In this study, the immunological response of macrophage cells subjected to CSCCAN was studied with regard to expression of pro-inflammatory cytokine, interleukin 1 beta (IL)-1 $\beta$, after $3 \mathrm{~h}$ incubation (Figure 4a). The RT-PCR analysis revealed that cells treated with nanoparticle concentrations up to $100 \mu \mathrm{g} / \mathrm{mL}$ did not stimulate a significant increase in expression of IL1- $\beta$ gene, which is associated with inflammation and toxicity signaling pathways in vitro. IL-1 $\beta$ mRNA was only detected in the cells treated with bacterial lipopolysaccharides (positive control). However, the intensity of the band and gene expression pattern for $\beta$-actin mRNA (loading control) (Figure $4 \mathrm{~b}$ ) was similar to that of IL-1 $\beta$ gene extracted from cells treated with bacterial lipopolysaccharides. This result implies that CSCCAN does not elicit an immediate immunological response nor does it stimulate the production of pro-inflammatory proteins, a critical indicator of toxicity [57].

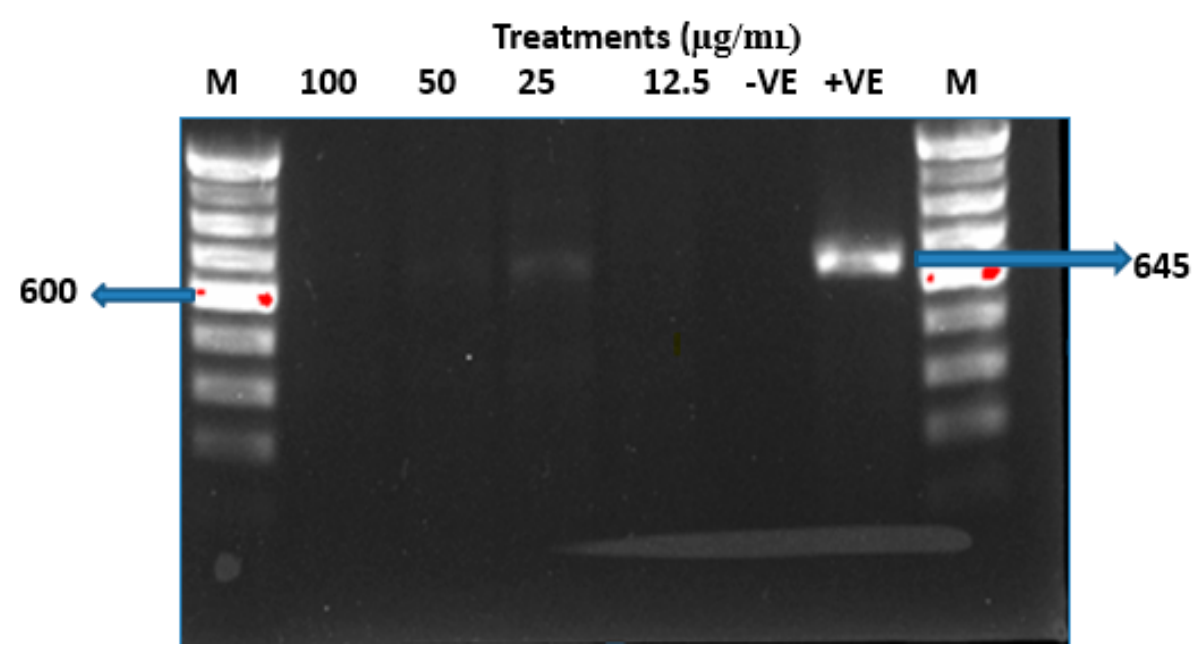

(a)

Treatments $(\mu \mathrm{g} / \mathrm{mu})$

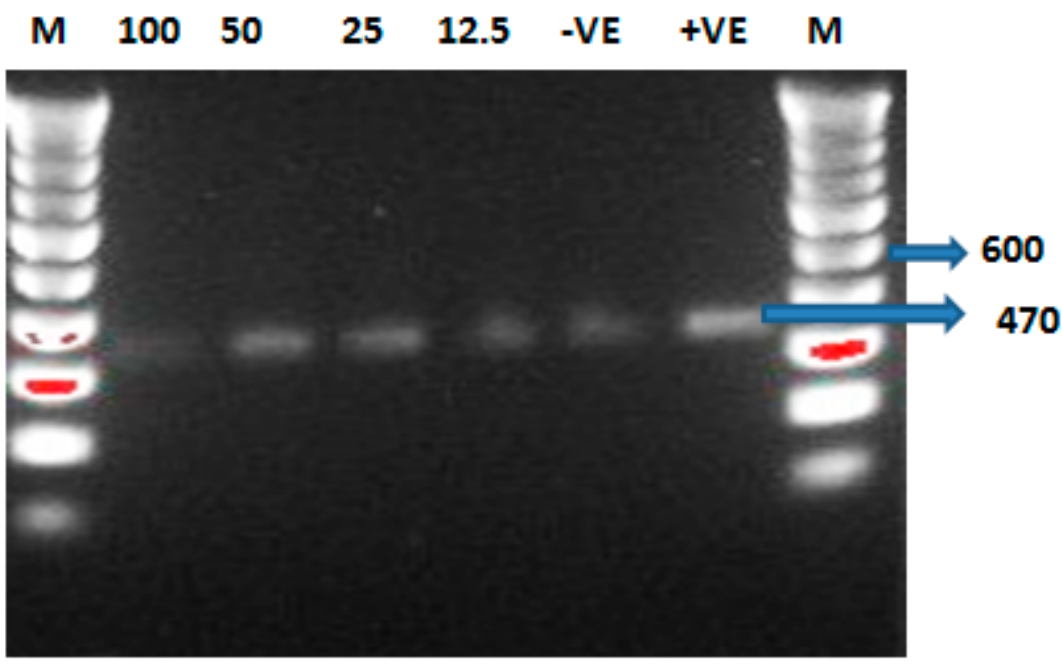

(b)

Figure 4. RT-PCR data showing IL-1 $\beta$ (a) and $\beta$-actin (loading control) (b), mRNA expressions after $3 \mathrm{~h}$ of CSCCAN treatment. -VE, negative control or untreated cells; +VE, positive control (Treated with Bacterial lipopolysaccharides); M, molecular weight markers (100 bp); DNA ladder MW, 600; IL-1 $\beta$ product size, 645 ; $\beta$-actin product size, 470. 


\subsubsection{Viability Test}

Addressing the cytotoxicity of the nano-antimicrobial agent against eukaryotic cell line prior to its intended application is an important step [58,59]. Macrophage cells treated with different concentrations of the nanoparticle formulations and ciprofloxacin (control), 100, 50, 25, 12.5 and $6.75 \mu \mathrm{g} / \mathrm{mL}$, were assessed using MTT assay for cell-viability determination (Figure 5). After $24 \mathrm{~h}$ treatment, the macrophage J774.1A cells showed more than $80 \%$ viability at $100 \mu \mathrm{g} / \mathrm{mL}$ of CSCCAN and C-CSCCAN, using doses above minimum inhibitory concentrations for the bacteria tested in this study, which was better than that of free ciprofloxacin $(p<0.05)$. However, the cytotoxicity assay showed an insignificant concentration-dependent viability. The cell viability dropped slightly at the formulations concentration of 50 and $100 \mu \mathrm{g} / \mathrm{mL}$. This observation indicates biocompatibility of CSCCAN and C-CSCCAN.

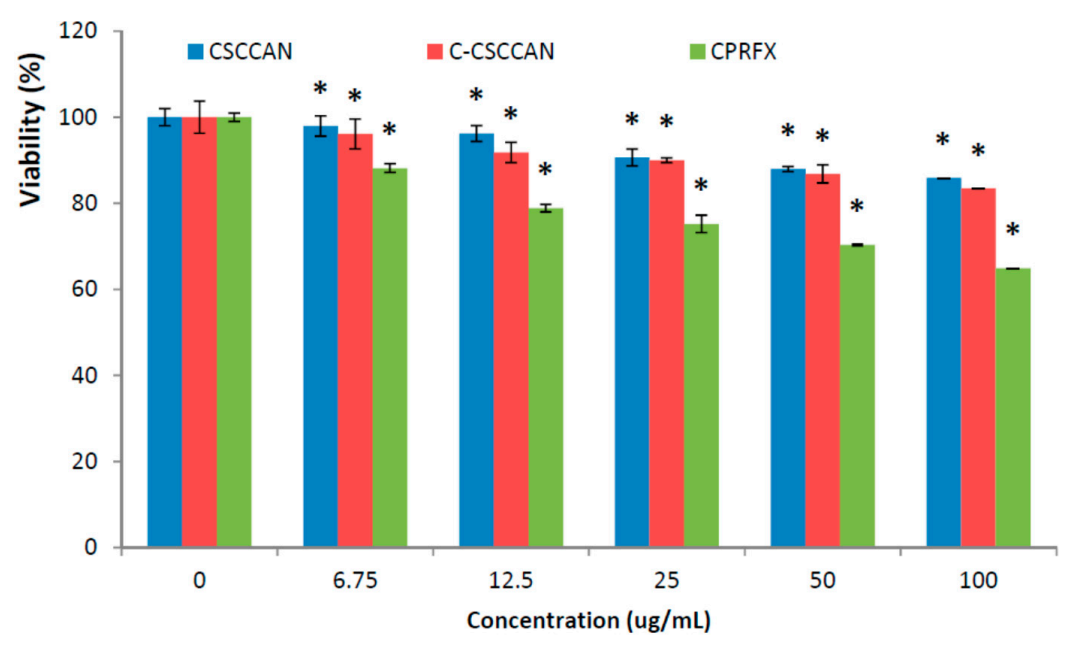

Figure 5. The MTT percentage viability of proliferating cells. The values represent mean \pm standard deviation $(=3) ;{ }^{*}(p<0.05)$ compared with ciprofloxacin $(\mathrm{CPRFX})$.

The comparison of the effect of the complex formulations on cell viability against free ciprofloxacin allows us to truly have a better insight into the complicated problem of toxicity. When free ciprofloxacin was used in similar doses, there was a considerable decrease in cell viability. This slight reduction in the cell number could be due to stress caused to the cells, signifying possible cytotoxic effect of the drug. Moreover, ciprofloxacin cytotoxic effects have been reported including its proapoptotic effects in Jurkat $\mathrm{T}$ cell in vitro [60], activation of monocytes and macrophages [61], and in vitro heritable genotoxic effects on human liver cells [62]. Ciprofloxacin was also found to stimulate cytotoxicity in human fibroblast cell cultures linked to oxidative stress [63]. The mechanism of experimental ciprofloxacin cytotoxicity has been correlated to selective reduction of mitochondrial-DNA in the course of an interference with a mitochondrial topoisomerase II-like activity [63,64].

The results in this study suggest biocompatibility of C-CSCCAN as a potential nano-antimicrobial agent and thus foretell its suitability for biological applications particularly in the systemic intracellular drug delivery. In addition, the choice of the $24 \mathrm{~h}$ incubation period was to mimic tissue-therapeutic contact time, which will be expected in an in vivo experiment where clearance (uptake) would take longer. Furthermore, the $24 \mathrm{~h}$ exposure was chosen since the cells could be within a logarithmic growth phase. In this period, any toxicity as a result to inhibition of proliferation and/or cell death, will be visibly in the MTT assay [65].

\subsubsection{Genotoxicity Test}

Damage to DNA may occur through indirect mechanisms whereby the nanomaterials do not physically interact with the DNA molecule. Additionally, nanomaterials may induce other cellular 
responses that consequently result in genotoxicity, such as oxidative stress, inflammation and abnormal signaling responses [66]. 5-bromo-2'-deoxyuridine (BrdU) is a substitute of thymidine nucleotide that can be incorporated instead of the thymidine during DNA replication. Once DNA is damaged as a result of external stimuli, the BrdU is not integrated to the newly synthesized DNA during replication process signifying genotoxic effect [67].

The BrdU assay was used in the present study with the macrophages J774A.1 cells to evaluate DNA damage and genotoxicity to individual cell population. Cells were treated with different concentrations of the nanoparticles formulations and ciprofloxacin (positive control). The percentage of labeled precursor (BrdU) incorporation into the cells indicated that nanoparticles formulations caused insignificant DNA damage; hence, they were non-genotoxic (Figure 6). It also showed no considerable difference between the formulations at various treatment groups.

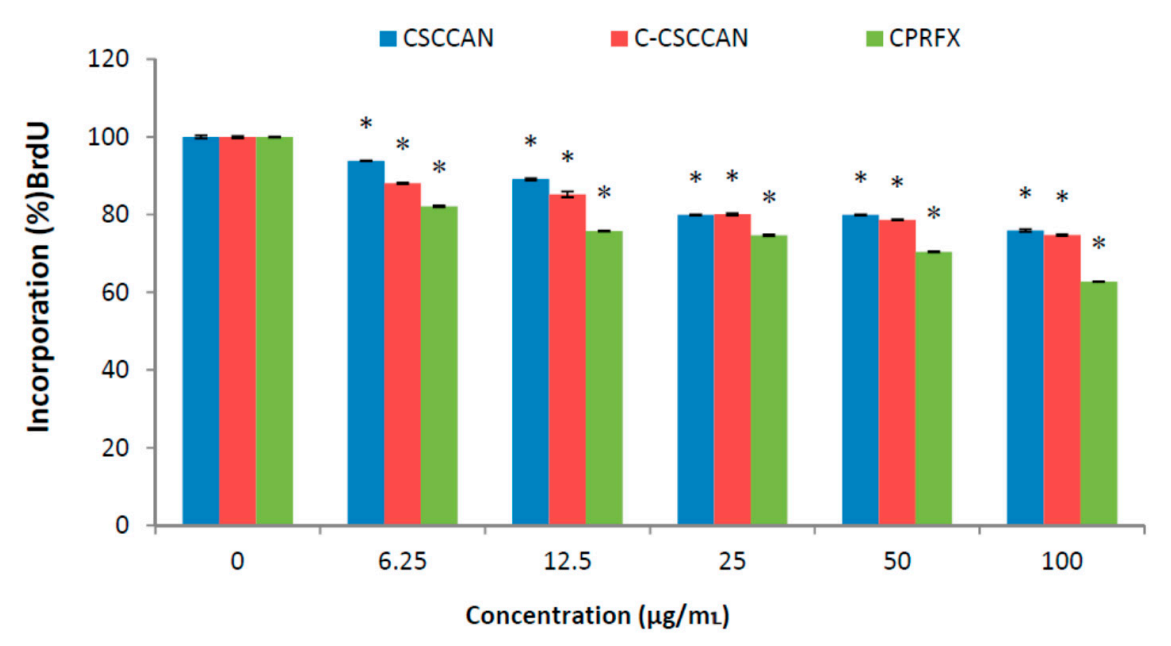

Figure 6. The percentage of BrdU incorporation into the DNA of proliferating cells. The values represent mean \pm standard deviation $(n=3) ;{ }^{*}(p<0.05)$ compared with ciprofloxacin.

\subsection{Antibacterial Activity}

The diameter of inhibition zone reflects magnitude of susceptibility of microorganisms [68]. The antibacterial activities of C-CSCCAN and free ciprofloxacin against $S$. Typhimurium strain was evaluated using the impregnated disk diffusion method. The antibacterial activities of ciprofloxacin were increased in the presence of CSCCAN against the test strain. The mean diameter zones of inhibition (Table 1, Figure 7) were $18.6 \pm 0.5$ and $11.7 \pm 0.9$ for C-CSCCAN and ciprofloxacin impregnated disks, respectively. The former represent almost $48 \%$ greater efficiency than that observed with the latter. Conversely, the nude CSCCAN did not present any inhibition zone diameter value. In the case of the C-CSCCAN, as compared to ciprofloxacin, the mean diameter zone of inhibition values was increased significantly $(p<0.05)$.

Table 1. Mean zone of inhibition ( $\mathrm{mm}$ ) of free ciprofloxacin, C-CSCCAN and CSCCAN suspension $(10 \mu \mathrm{L})$.

\begin{tabular}{cccc}
\hline Formulations & C-CSCCAN & Ciprofloxacin & CSCCAN \\
\hline Tested Bact. & - & - & - \\
S. Typhimurium & $18.6 \pm 0.5$ & $11.7 \pm 0.9$ & $\mathrm{~N} / \mathrm{I}$ \\
\hline
\end{tabular}

The values represent mean \pm standard deviation $(n=3) ; p>0.05$ compared with ciprofloxacin. N/I, No inhibition; C-CSCCAN, ciprofloxacin-encapsulated cockle shells calcium carbonate aragonite nanoparticles; CSCCAN, cockle shells calcium carbonate aragonite nanoparticles. 


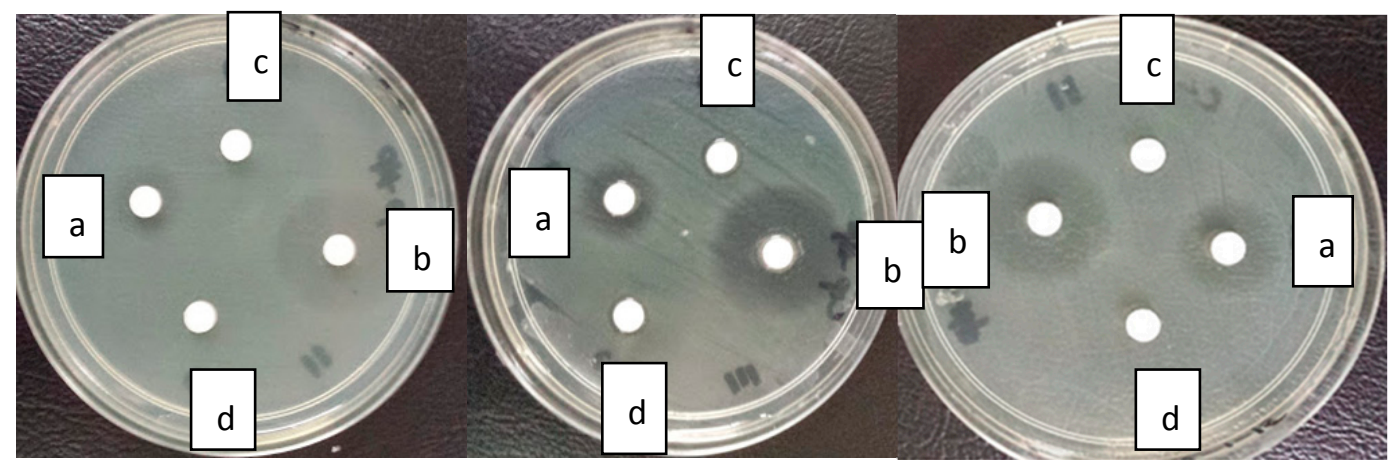

Figure 7. Disk diffusion assay displaying zone of inhibition diameter of ciprofloxacin (a); ciprofloxacin-cockle shells calcium carbonate aragonite nanoparticles (b); cockle shells calcium carbonate aragonite nanoparticles (c); and dimethylsulfoxide (d).

The results suggest that while CSCCAN has no antibacterial activity against $S$. Typhimurium, its preparation with ciprofloxacin enhanced the antibacterial activity of the antibiotic. In a similar development, Banoee et al. (2009) reported an in vitro enhanced antibacterial activity of ciprofloxacin in combination with $\mathrm{ZnO}$ nanoparticles against Staphylococcus aureus and Escherichia coli, which was suggested to the direct nanoparticle interference with NorA protein pumping activity of the tested organisms [24]. Similarly, time dependent studies have demonstrated similar improvements in antimicrobial activity of ciprofloxacin encapsulated in carrier system, shortened the time of sterilization $[38,69]$.

Many studies have described the enormous benefits with nano-particulate delivery systems, including the sustained release of antibiotic for prolonged durations, which in turn used to attain the minimum inhibitory concentration for extended time [51]. The data obtained in the present study may declare that encapsulated ciprofloxacin were successfully prepared and was continuously released from nanoparticles for a longer period, thus significantly extended the drug effect compare to the free ciprofloxacin. The higher the antibacterial effect of ciprofloxacin-nanoparticles may have resulted from higher diffusion of the nanoparticles through the bacteria. This indicates that the effective dose of this antibiotic can be reduced against $S$. Typhimurium, thereby reducing the side effects of the drug. It has been revealed that nanoparticles are able to be endocytose by phagocytic cells and release the drug into the cells $[9,70]$. The ciprofloxacin loaded nanoparticles could be useful in the targeting of the drug to the phagocytic cells to improve the treatment of intracellular infections compared to the treatment using free ciprofloxacin.

\section{Materials and Methods}

\subsection{Reagents, Chemicals and Media}

Polysorbate-Tween 80 (Thermo Fisher Scientific, Waltham, MA, USA), glyceride (Sigma-Aldrich Co., St. Louis, MO, USA), ciprofloxacin (LKT Laboratories, St. Paul, MN, USA), dulbecco's modified eagle's medium (Sigma-Aldrich Co.), foetal bovine serum (Sigma-Aldrich Co.), mueller-hinton agar (Difco Becton Dickinson, Sparks, MD, USA), mueller-hinton broth (Difco Becton Dickinson), ethanol (Joseph Mills Denaturants, Liverpool, UK), phosphate buffer saline (Sigma-Aldrich Co.), dimethylsulfoxide (Sigma-Aldrich Co.), MTT (3-(4,5-dimethylthiazol-2-yl)-2,5 diphenyltetrazolium bromide) dye (Naclai tesque, Inc., Kyoto, Japan), penicillin and streptomycin antibiotics (i-DNA Biotecnology(M) Sdn Bhd, Kuala Lumpur, Malaysia), Access RT-PCR System (Promega Corp., Madison, WI, USA), lipopolysaccharides from Salmonella enterica serotype enteritidis (Sigma-Aldrich Co.), RNA isolation kit (RBC Bioscience Corp., Xiandin Dist., New Taipei, Taiwan), BrdU cell proliferation assay kit (Biovision Inc., Milpitas, CA, USA), agarose LE, analytical grade (Promega Corp.), SYBR Safe DNA gel stain (Invitrogen, Waltham, MA, USA), loading dye and DNA ladder (i-DNA Biotechnology (M) Sdn Bhd). 


\subsection{Bacterial Strain}

Salmonella Typhimurium ATCC 14208 was obtained from American Type Culture Collection (ATCC, Rockville, MD, USA). S. Typhimurium ATCC 14028 were grown and maintained on Tryptic Soy agar (TSA) (Sigma-Aldrich Co.).

\subsection{Top-Down Synthesis of Cockle Shells Calcium Carbonate Nanoparticles}

The synthesis of the nanoparticles was achieved via oil-in-water $(\mathrm{O} / \mathrm{W})$ microemulsions using a high pressure homogenizer (HPH) [71,72]. The microemulsion samples were prepared by mixing the surfactant and co-surfactant (Tween- 80 and glycerol) into $20 \mathrm{~mL}$ oil in a glass reactor followed by addition of the $65 \mathrm{~mL}$ deionized water. The mixed solutions were stirred for $30 \mathrm{~min}$ until they became transparent. The nanoparticles were first prepared by suspending 2 gram of dry cockle shells-calcium carbonate powder (CSCCP) into the formulated oil-in-water $(\mathrm{O} / \mathrm{W})$ microemulsion, and moderately stirred for $10 \mathrm{~min}$ at $1000 \mathrm{rpm}$ to form a cockle shells calcium carbonate suspension. The formulated suspension was sucked through the fluid opening tube of $\mathrm{HPH}$ for pre-milling at low pressures of 200 and 500 bars for three cycles each. After pre-milling, the suspension was collected at the HPH outlet and was again passed through the HPH fluid inlet at a high pressure of 1500 bars for 25 homogenizing cycles to get the desired fine particles. The final particles suspension was filtered and oven dried at $95^{\circ} \mathrm{C}$ for $24 \mathrm{~h} \mathrm{[26].}$

\subsection{Drug Loading and Encapsulation}

An optimized aqueous solution of ciprofloxacin $(3 \mathrm{mg} / \mathrm{mL})$ was added into the CSCCAN suspension $(50 \mathrm{mg} / \mathrm{mL})$. The formulation was mechanically agitated overnight at $200 \mathrm{rpm}$ at room temperature using a laboratory multi-hotplate stirrer (Witeg, Wise Stir SMHS, Witeg Labortechnik $\mathrm{GmbH}$, Wertheim, Germany). Then it was centrifuged at 15,000 rpm for $15 \mathrm{~min}$. The ciprofloxacin-cockle shell-derived calcium carbonate (aragonite) nanoparticles (C-CSCCAN) were freeze-dried [50].

The ciprofloxacin loading and encapsulation efficiency were analyzed by calculating the difference between the total drug $(W t)$ and the free encapsulated drug $(W f)$ in the nanoparticles supernatant per nanoparticles weight. The residual quantity of free encapsulated ciprofloxacin remaining in the supernatant was determined by computing the optical density at $291 \mathrm{~nm}$ [73], on a micro-titer plate reader (TECAN Safire, Tecan Austria GmbH, Grödig, Austria) [74]. A calibration curve of standard ciprofloxacin solution was used to obtain ciprofloxacin concentration $\left(R^{2}=0.9823, Y=0.0091 X+1.4894\right)$. Data were given as an average measurement of three independent values. Drug loading contents (LC\%) and encapsulation efficiency (EE\%) of the nanoparticle were calculated as previously described [75]:

$$
\text { Loading Content }=\frac{W t-W f}{W n p} \times 100
$$

where $W t=$ the total weight of drug used, $W f=$ the weight of non-encapsulated free drug, and Wnp = the weight of the nanoparticle.

$$
\text { Encapsulation Efficiency }=\frac{W t-W f}{W t} \times 100
$$

where $W t=$ the total weight of drug, and $W f=$ the weight of non-encapsulated free drug.

\subsection{Transmission Electron Microscopy}

The shape and particle size of CSCCAN and C-CSCCAN were analyzed using Transmission Electron Microscopy (TEM) (Hitachi H-7100, Tokyo, Japan). Samples were mixed with $95 \%$ alcohol then sonicated for $45 \mathrm{~min}$. The colloidal drop from each sample were loaded on carbon coated copper 
grids, placed on a filter paper, and dried at room temperature for $1 \mathrm{~h}$. TEM measurements were carried out at 150 kilovolts [76].

\subsection{Field Emission Scanning Electron Microscope}

The surface morphology of nude CSCCAN and C-CSCCAN were observed with Field Emission Scanning Electron Microscope (FESEM) (Model 100, Perkin Elmer, 710 Bridge port Avenue, Shelton, CT, USA), equipped with an energy-dispersive X-ray spectroscopy. The samples were individually prepared on aluminum stubs and coated with gold under argon atmosphere using a sputter coater. The FESEM observations were performed at 200 kilovolts.

\section{7. $\zeta$ Potential}

The particle surface charge was measured using Malvern Zetasizer Nano (Malvern Instruments, Worcestershire, UK), which measures the electrophoretic mobility of particles in an electrical field, which is then converted into $\zeta$ potential. The measurement was performed by injecting the samples into the cells of the zetasizer and run at room temperature. The process was done three times and the average was taken to determine the $\zeta$ potentials.

\subsection{X-ray Powder Diffraction}

The purity and crystalline properties of the CSCCAN, C-CSCCAN and free ciprofloxacin powders were investigated using X-ray Powder Diffraction (XRD) (Shimadzu XRD-6000, Yokohama, Kanagawa, Japan). Cross-section of the samples was taken and placed on a quartz plate for exposure to $\mathrm{Cu} \mathrm{K} \alpha$ radiation of wavelength $\lambda=1.5406 \AA$. The samples were then examined at room temperature over a $2 \theta$ range of $4^{\circ}-50^{\circ}$, with sampling intervals of $0.02^{\circ} 2 \theta$ and a scanning rate of $0.6^{\circ} / \mathrm{min}$.

\subsection{In Vitro Biocompatibility Assays}

\subsubsection{Cell Culture}

Macrophage J774A.1 cells were purchased from the American Type Culture Collection (ATCC). They were maintained as semi-adherent cell cultures at $37^{\circ} \mathrm{C}$ in a humidified atmosphere $\left(5 \% \mathrm{CO}_{2}\right)$ in Dulbecco modified Eagle's minimal essential medium (DMEM, $25 \mathrm{mM}$ glucose) supplemented with $10 \%$ heat-inactivated foetal bovine serum (FBS) and $100 \mu \mathrm{g} / \mathrm{mL}$ each of penicillin and streptomycin.

\subsubsection{RNA Extraction and RT-PCR}

Macrophages J774A.1 cells were seeded at a density of $5 \times 10^{5}$ cells/well in $2 \mathrm{~mL}$ medium of 6-wells culture plates and grown overnight. The cells were then washed with PBS and treated with different concentrations of CSCCAN in culture medium suspension (100-3.125 $\mu \mathrm{g} / \mathrm{mL})$ for $3 \mathrm{~h}$. Bacterial lipopolysacchride treated cells served as a positive control, and untreated cells served as a standard control for RT-PCR analysis. After exposure to nanoparticles, cells were collected, extracted and analyzed for mRNA expression of IL-1 $\beta$ cytokine. The pro-inflammatory cytokine, IL-1 $\beta$, was evaluated and $\beta$-actin was used as the control. The total RNA was extracted using the RBC Bioscience Total RNA Isolation kit, according to the manufacturer's instructions. RNA Quantification and purity was determined using NanoDrop Spectrophotometer. Primer sequences were designed on the NCBI website with accession number: NM_008361.3 and product size: 645 for IL-1 $\beta$ and $\beta$-actin with accession number: NM_013458.5 and product size: 470. The primers (Table 2) were supplied by (First Base Laboratories Sdn Bhd, Kuala Lumpur, Malaysia). Reverse transcription-PCR were performed according to the Access Reverse Transcriptase System Protocol in a sensquest labcycler under the following conditions: $45^{\circ} \mathrm{C}$ for $45 \mathrm{~min}, 94^{\circ} \mathrm{C}$ for $2 \mathrm{~min}, 94^{\circ} \mathrm{C}$ for $30 \mathrm{~s}, 65^{\circ} \mathrm{C}$ for $1 \mathrm{~min}$, $72{ }^{\circ} \mathrm{C}$ for $2 \mathrm{~min}$, and $68^{\circ} \mathrm{C}$ for $7 \mathrm{~min}$ for a total of 40 cycles. The same cycling conditions were used for $\beta$-actin with the exception of annealing temperature $\left(59^{\circ} \mathrm{C}\right.$ for $\left.1 \mathrm{~min}\right)$. The PCR amplification products 
were analyzed by gel electrophoresis on a $0.1 \%$ agarose gel, stained with SYBR Safe DNA Gel Stain, and fluoresce with ultraviolet source.

Table 2. Gene names and sequences of primers.

\begin{tabular}{cc}
\hline Gene Name & IL-1 $\beta$ \\
\hline $\begin{array}{c}\text { Forward Primer Sequences } \\
\text { Reverse Primer Sequence }\end{array}$ & GCTGCTTCCAAACCTTTGAC \\
\hline Gene Name & $\beta$-Actin \\
\hline Forward Primer Sequences & CATGAGGCTTATATCCTTGC \\
Reverse Primer Sequence & TAAAAGGCACTTTGTCCACT \\
\hline
\end{tabular}

\subsubsection{MTT—Viability Assay}

For cytocompatibility study, macrophages J774A.1 were split by mechanical scraping and cell suspensions were seeded in 96-well micro-titer plate at a density of 10,000 cells/well and incubated for $24 \mathrm{~h}$. During each experiment, the media was removed and the cells were cultured with $100 \mu \mathrm{L}$ of different concentrations of C-CSCCAN, CSCCAN and ciprofloxacin in culture medium (100 to $6.25 \mu \mathrm{g} / \mathrm{mL}$ ), or of the control (culture medium only). The experiment was conducted in triplicates, and the optical densities were measured at $570 \mathrm{~nm}$ in a micro-titer plate reader $[50,74]$. The cell viability was computed using the following equation:

$$
\text { Cell Viability }(\%)=\mathrm{A}_{\text {test }} / \mathrm{A}_{\text {control }} \times 100
$$

where $A_{\text {test }}$ is the optical density of the cells incubated with the different treatments and $A_{\text {control }}$ is the optical density of the cells incubated with the culture medium only (negative control). The cytotoxicity was determined from the average of three replicate tests and results were expressed as mean \pm standard deviation.

\subsubsection{BrdU (ELISA) Genotoxicity Assay}

The cell genotoxicity and quantitative determination of DNA synthesis in cells was evaluated based on the incorporation of BrdU into the synthesized DNA of a proliferating cell [67]. Macrophages J774A.1 cells were seeded into 96-well micro-titer plate at density at a density of $1 \times 10^{4}$ cells per well and incubated for $24 \mathrm{~h}$. The cells were then washed with PBS and treated with different concentrations of C-CSCCAN, CSCCAN and ciprofloxacin in culture medium suspension (100-3.125 $\mu \mathrm{g} / \mathrm{mL})$. Cells incubated with culture medium only (untreated cells) were regarded as negative control. After the cell incubation for $24 \mathrm{~h}$, the medium was removed and the BrdU labeling assay was performed according to the manufacturer's instructions (Bio Vision Incorporated, Milpitas, CA, USA). The color intensity absorbance directly correlated to the amount of synthesized DNA, which also reflects the number of proliferating cells. The BrdU incorporation was determined by analyzing cells treated compared to controls and the absorbance was measured at $450 \mathrm{~nm}$ using a micro-titer plate reader [67]. The data were determined from the average of three replicate tests and results were expressed as mean \pm standard deviation.

\subsection{In Vitro Antibacterial Susceptibility Test}

The bacterial stock solution were diluted according to the method in Clinical and Laboratory Standards Institute (CLSI) [77].

\subsubsection{Preparation of Drugs Stock Solutions}

A stock solution of C-CSCCAN suspensions and ciprofloxacin dispersion ( $\mathrm{pH}$ 7.4) at concentration of $1 \mathrm{mg} / \mathrm{mL}$ was prepared in $10 \%$ DMSO. 


\subsubsection{Disc Diffusion Susceptibility Assay}

Susceptibility of C-CSCCAN and ciprofloxacin against $S$. Typhimurium were determined by disc diffusion method described previously [78], with little modifications. This method was performed in Muller Hinton agar media. A single colony of $S$. Typhimurium was grown overnight in MHB on a rotary shaker $(250 \mathrm{rpm})$ at $35^{\circ} \mathrm{C}$. Inoculums were prepared by diluting the overnight cultures to a $10^{6}$ colony-forming units $/ \mathrm{mL}$ (CFU/mL) suspension according to the turbidity of $0.5 \mathrm{McFarland}$ standards. Then, $100 \mu \mathrm{L}$ bacterial suspensions were inoculated to the prepared MHA plates and spread all over in one direction. Sterile paper disc ( $6 \mathrm{~mm}$ in diameter) was placed on the MHA plates and impregnated with $10 \mu \mathrm{L}$ of C-CSCCAN formulation and CSCCAN $(100 \mu \mathrm{g} / \mathrm{mL})$. Ciprofloxacin $(100 \mu \mathrm{g} / \mathrm{mL})$ and DMSO was correspondingly prepared and served as a positive and negative control respectively. After $37^{\circ} \mathrm{C}$ incubation for $24 \mathrm{~h}$, the diameters of inhibition zone were measured in millimeters. The data obtained from three replicate tests were expressed as mean \pm SD.

\subsection{Statistical Analysis}

All statistical analyses were performed using Minitab statistical software (Minitab Inc., State College, PA, USA). All experiments were performed in triplicate. Values were expressed as mean \pm standard deviation. Comparisons of treatment effects and statistical significant differences between groups were determined using one-way analysis of variance (ANOVA) (for MTT and BrdU Assay) and Student's independence $t$-test (for disc diffusion assay). A value of $p<0.05$ was regarded significant unless indicated otherwise.

\section{Conclusions}

The aim of nano-antibacterial therapy is to achieve delivery of drug molecules, especially in the sub-cellular organelles. This study shows that the physicochemical properties of CSCCAN were the major factors influencing the antibacterial performance and increased susceptibility of $S$. Typhimurium. The encapsulation and subsequent sustained slow released of ciprofloxacin possibly modified and increased the drug cellular permeation, half-life and reduced its efflux to allow maximum tolerated dose. The outcome of antibacterial study bears significant implications, because a reduction in dose frequency due to delivery of drug molecules inside the cells would indeed enhance patient compliance and the safety of treatment and it could offer a great possibility to overcome the emerging problem of antibiotic resistance among a range of disease causing bacteria. The present study has demonstrated the biocompatibilities (nontoxicity and nonimmunogenicity) of CSCCAN and its ciprofloxacin formulation, making them suitable candidates for nanomedicine and related fields.

Author Contributions: Tijani Isa and Zuki Abu Bakar Zakaria conceived and designed the experiments; Tijan Isa, Yaya Rukayadi, Alhaji Zubair Jaji, Mustapha Umar Imam, Nahida Ibrahim Hammadi, and Saffaanah Khuder Mahmood performed the experiments; Tijani Isa, Yaya Rukayadi, Alhaji Zubair Jaji and Mustapha Umar Imam analyzed the data; Zuki Abu Bakar Zakaria; Mustapha Umar Imam and Mohd Noor Mohd Hezmee contributed reagents/materials/analysis tools; Tijani Isa wrote the paper.

Conflicts of Interest: The authors declare no conflict of interests.

\section{References}

1. Hajipour, M.J.; Fromm, K.M.; Ashkarran, A.A.; Jimenez de Aberasturi, D.; de Larramendi, I.R.; Rojo, T. Antibacterial properties of nanoparticles. Trends Biotechnol. 2012, 30, 499-511. [CrossRef] [PubMed]

2. Pinto-Alphandary, H.; Andremont, A.; Couvreur, P. Targeted delivery of antibiotics using liposomes and nanoparticles: Research and applications. Int. J. Antimicrob. Agents 2000, 13, 155-168. [CrossRef]

3. Pestova, E.; Millichap, J.J.; Noskin, G.A.; Peterson, L.R. Intracellular targets of moxifloxacin: A comparison with other fluoroquinolones. J. Antimicrob. Chemother. 2000, 45, 583-590. [CrossRef] [PubMed]

4. Bambeke, F.V.; Balzi, E.; Tulkens, M. Antibiotic efflux pumps franc. Biochem. Pharmacol. 2000, 60, 457-470. [CrossRef] 
5. Singh, M.; Jadaun, G.P.S.; Ramdas, S.K.; Chauhan, V.; Mishra, R. Effect of efflux pump inhibitors on drug susceptibility of ofloxacin resistant Mycobacterium tuberculosis isolates. Indian J. Med. Res. 2011, 133, 535-540. [PubMed]

6. Ahmed, A.; Ibrahim, M.; Abu-sef, F.A.; Hassan, Z.; Mohamed, S.; Mohamed, N. Contribution of different mechanisms to the resistance to fluoroquinolones in clinical isolates of Salmonella enterica. Braz. J. Infect. Dis. 2013, 7, 431-437.

7. Carryn, S.; Chanteux, H.; Seral, C.; Mingeot-Leclercq, M.P.; van Bambeke, F.; Tulkens, P.M. Intracellular pharmacodynamics of antibiotics. Infect. Dis. Clin. N. Am. 2003, 17, 615-634. [CrossRef]

8. Jacoby, G.A. Mechanisms of resistance to quinolones. Clin. Infect. Dis. 2005, 41, S120-S126. [CrossRef] [PubMed]

9. Briones, E.; Colino, C.I.; Lanao, J.M. Delivery systems to increase the selectivity of antibiotics in phagocytic cells. J. Control. Release 2008, 125, 210-227. [CrossRef] [PubMed]

10. Webb, M.S.; Boman, N.L.; Wiseman, D.J.; Saxon, D.; Sutton, K.; Wong, K.F. Antibacterial efficacy against an in vivo Salmonella typhimurium infection model and pharmacokinetics of a liposomal ciprofloxacin formulation. Antimicrob. Agents Chemother. 1998, 42, 45-52. [PubMed]

11. Bhalerao, S.R.; Rote, A.R. Application of UV spectrophotometric methods for estimation of ciprofloxacin and tinidazole in combined tablet dosage form. Int. J. Pharmacol. Pharm. Sci. 2012, 4, 4-7.

12. George, R.S.; Adrienne, L.W. Delmar Nurse's Drug Handbook 2012 Edition, 21st ed.; West Virginia University, Cengage Learning: Clifton Park, NY, USA, 2011; Volume 2012, p. 22.

13. Imbuluzqueta, E.; Gamazo, C.; Ariza, J.; Blanco-Prieto, M.J. Drug delivery systems for potential treatment of intracellular bacterial infections. Front. Biosci. 2010, 15, 397-417. [CrossRef]

14. Piddock, L.J.V.; Garvey, M.I.; Rahman, M.M.; Gibbons, S. Natural and synthetic compounds such as trimethoprim behave as inhibitors of efflux in Gram-negative bacteria. J. Antimicrob. Chemother. 2010, 65, 1215-1223. [CrossRef] [PubMed]

15. Zhao, D.; Zhuo, R.X.; Cheng, S.X. Modification of calcium carbonate based gene and drug delivery systems by a cell-penetrating peptide. Mol. BioSyst. 2012, 8, 3288-3294. [CrossRef] [PubMed]

16. Pelgrift, R.Y.; Friedman, A.J. Nanotechnology as a therapeutic tool to combat microbial resistance. Adv. Drug Deliv. Rev. 2013, 65, 1803-1815. [CrossRef] [PubMed]

17. Plapied, L.; Duhem, N.; des Rieux, A.; Préat, V. Fate of polymeric nanocarriers for oral drug delivery. Curr. Opin. Colloid Interface Sci. 2011, 16, 228-237. [CrossRef]

18. Blecher, K.; Nasir, A.; Friedman, A. The growing role of nanotechnology in combating infectious disease. Virulence 2011, 2, 395-401. [CrossRef] [PubMed]

19. Huh, A.J.; Kwon, Y.J. “Nanoantibiotics”: A new paradigm for treating infectious diseases using nanomaterials in the antibiotics resistant era. J. Control. Release 2011, 156, 128-145. [CrossRef] [PubMed]

20. Huang, C.M.; Chen, C.H.; Pornpattananangkul, D.; Zhang, L.; Chan, M.; Hsieh, M.F. Eradication of drug resistant Staphylococcus aureus by liposomal oleic acids. Biomaterials 2011, 32, 214-221. [CrossRef] [PubMed]

21. Akbari, V.; Abedi, D.; Pardakhty, A.; Sadeghi-Aliabadi, H. Ciprofloxacin nano-niosomes for targeting intracellular infections: An in vitro evaluation. J. Nanopart. Res. 2013, 15. [CrossRef]

22. Hono, S.C.; Anino, T.T.; Eki, T.S.; Orimoto, K.M. Pharmacokinetic and pharmacodynamic efficacy of intrapulmonary administration of ciprofloxacin for the treatment of respiratory infections. Drug Metab. Pharmacokinet. 2007, 22, 88-95.

23. Ong, H.X.; Traini, D.; Cipolla, D.; Gonda, I.; Bebawy, M.; Agus, H. Liposomal nanoparticles control the uptake of ciprofloxacin across respiratory epithelia. J. Pharm. Res. 2012, 29, 3335-3346. [CrossRef] [PubMed]

24. Banoee, M.; Seif, S.; Nazari, Z.E.; Jafari-Fesharaki, P.; Shahverdi, H.R.; Moballegh, A. ZnO nanoparticles enhanced antibacterial activity of ciprofloxacin against Staphylococcus aureus and Escherichia coli. J. Biomed. Mater. Res. Part B Appl. Biomater. 2010, 93, 557-561. [CrossRef] [PubMed]

25. Mohamed, M.; Yousuf, S.; Maitra, S. Decomposition study of calcium carbonate in cockle shell. J. Eng. Sci. Technol. 2012, 7, 1-10.

26. Rodríguez-Ruiz, I.; Delgado-López, J.M.; Durán-Olivencia, M.A.; Iafisco, M.; Tampieri, A.; Colangelo, D. $\mathrm{PH}-$ responsive delivery of doxorubicin from citrate-apatite nanocrystals with tailored carbonate content. Langmuir 2013, 29, 8213-8221. [CrossRef] [PubMed] 
27. Kamba, A.S.; Ismail, M.; Azmi, T.; Ibrahim, T.; Abubakar, Z.Z. Synthesis and characterisation of calcium carbonate aragonite nanocrystals from cockle shell powder (Anadara granosa). J. Nanomater. 2013, 2013. [CrossRef]

28. Lucas-Girot, A.; Verdier, M.C.; Tribut, O.; Sangleboeuf, J.C.; Allain, H.; Oudadesse, H. Gentamicin-loaded calcium carbonate materials: Comparison of two drug-loading modes. J. Biomed. Mater. Res. Part B Appl. Biomater. 2005, 73, 164-170. [CrossRef] [PubMed]

29. Kroll, A.; Pillukat, M.H.; Hahn, D.; Schnekenburger, J. Interference of engineered nanoparticles with in vitro toxicity assays. Arch. Toxicol. 2012, 86, 1123-1136. [CrossRef] [PubMed]

30. Samberg, M.E.; Oldenburg, S.J.; Monteiro-Riviere, N.A. Evaluation of silver nanoparticle toxicity in skin in vivo and keratinocytes in vitro. Environ. Health Perspect. 2010, 118, 407-413. [CrossRef] [PubMed]

31. McNeil, S.E. Immunological properties of engineered nanomaterials. Nat. Nanotechnol. 2007, 2, 469-478.

32. Yang, E.; Jang, J.; Lim, D.; Choi, I. Enzyme-linked immunosorbent assay of IL-8 production in response to silver nanoparticles. Totowa Natl J. Humana Press 2012, 926, 131-139.

33. Dong, Y.; Ying, C.; Li-Hong, D.; Yu-Jiang, Z. Controllable synthesis of $\mathrm{CaCO}_{3}$ micro/anocrystals with different morphologies in microemulsion. Chem. Res. Chin. Univ. 2010, 26, 678-682.

34. Wada, N.; Seiichi, S.; Kiyoshi, K.; Takao, U. Formation of thin calcium carbonate films with aragonite and vaterite forms coexisting with polyacrylic acids and chitosan membranes. J. Colloid Interface Sci. 2004, 279, 167-174. [CrossRef] [PubMed]

35. Zou, W.; Liu, C.; Chen, Z.; Zhang, N. Preparation and characterization of cationic PLA-PEG nanoparticles for delivery of plasmid DNA. Nanoscale Res. Lett. 2009, 4, 982-992. [CrossRef] [PubMed]

36. Velázquez-Castillo, R.; Reyes-Gasga, J.; García-Gutierrez, D.I.; Jose-Yacaman, M. Nanoscale characterization of nautilus shell structure: An example of natural self-assembly. J. Mater. Res. 2006, 21, 1484-1489. [CrossRef]

37. Das, S.; Banerjee, R.; Bellare, J. Aspirin loaded albumin nanoparticles by coacervation: Implications in drug delivery. Trends Biomater. Artif. Organs. 2005, 18, 203-212.

38. Mao, Z.; Ma, L.; Gao, C.; Shen, J. Preformed microcapsules for loading and sustained release of ciprofloxacin hydrochloride. J. Control. Release 2005, 104, 193-202. [CrossRef] [PubMed]

39. Hua, A.; Steven, A.; Jones de Villiers, M.M.; Yuri, M.L. Nano-encapsulation of furosemide microcrystals for controlled drug release. J. Control. Release 2003, 86, 59-68.

40. Balabushevitch, N.G.; Sukhorukov, G.B.; Moroz, N.A.; Volodkin, D.V.; Larionova, N.I.; Donath, E. Encapsulation of proteins by layer-by-layer adsorption of polyelectrolytes onto protein aggregates: Factors regulating the protein release. Biotechnol. Bioeng. 2001, 76, 207-213. [CrossRef] [PubMed]

41. Shchukin, D.G.; Patel, A.A.; Sukhorukov, G.B.; Lvov, Y.M. Nanoassembly of biodegradable microcapsules for DNA encasing. J. Am. Chem. Soc. 2004, 126, 3374-3375. [CrossRef] [PubMed]

42. Jeong, Y.-II.; Na, H.-S.; Seo, D.-H.; Kim, D.-G.; Lee, H.-C.; Jang, M.-K.; Nah, J.W. Ciprofloxacin-encapsulated poly(DL-lactide-co-glycolide) nanoparticles and its antibacterial activity. Int. J. Pharm. 2008, 352, 317-323. [CrossRef] [PubMed]

43. Tuck-Yun, C.; Sheng-Ming, W.; Zuo-Jun, H.; Zhou-Hao, X.; Guang-Qi, C.; Chen, Y.; Yong, L.; Hui, Z.; $\mathrm{An}-\mathrm{Wu}, \mathrm{X}$. Calcium carbonate/CaIP6 nanocomposite particles as gene delivery vehicles for human vascular smooth muscle cells. J. Mater. Chem. 2010, 20. [CrossRef]

44. Abreu, F.O.M.S.; Forte, M.M.C.; Kist, T.B.L.; Honaiser, L.P. Effect of the preparation method on the drug loading of alginate-chitosan microspheres. Express Polym. Lett. 2010, 4, 456-464. [CrossRef]

45. Ren, G.; Hu, D.; Cheng, E.W.C.; Vargas-Reus, M.A.; Reip, P.; Allaker, R.P. Characterisation of copper oxide nanoparticles for antimicrobial applications. Int. J. Antimicrob. Agents 2009, 33, 587-590. [CrossRef] [PubMed]

46. Mu, L.; Feng, S.S. PLGA/TPGS nanoparticles for controlled release of paclitaxel: Effects of the emulsifier and drug loading ratio. Pharm. Res. 2003, 20, 1864-1872. [CrossRef] [PubMed]

47. Liu, Y.; Reineke, T.M. Hydroxyl stereochemistry and amine number within poly(glycoamidoamine)s affect intracellular DNA delivery. J. Am. Chem. Soc. 2005, 127, 3004-3015. [CrossRef] [PubMed]

48. Shang, L.; Karin, N.; Gerd, U.N. Engineered nanoparticles interacting with cells: Size matters. J. Nanobiotechnol. 2014, 12. [CrossRef] [PubMed]

49. Ahsan, F.; Rivas, I.P.; Khan, M.A.; Torres Suárez, A.I. Targeting to macrophages: Role of physicochemical properties of particulate carriers-Liposomes and microspheres-On the phagocytosis by macrophages. J. Control. Release 2002, 79, 29-40. [CrossRef] 
50. Kamba, S.A.; Ismail, M.; Hussein-al-ali, S.H.; Azmi, T.; Ibrahim, T.; Abubakar, Z.Z. In vitro delivery and controlled release of doxorubicin for targeting osteosarcoma bone cancer. Molecules 2013, 18, 10580-10598. [CrossRef] [PubMed]

51. Jain, D.; Banerjee, R. Comparison of ciprofloxacin hydrochloride-loaded protein, lipid, and chitosan nanoparticles for drug delivery. J. Biomed. Mater. Res. Part B Appl. Biomater. 2008, 86, 105-112. [CrossRef] [PubMed]

52. Voort, J.; van den Mooter, G.; Verheyden, L.; Ludwig, A. Factorial design, physicochemical characterisation and activity of ciprofloxacin-PLGA nanoparticles. Int. J. Pharm. 2004, 275, 171-187.

53. Surajit, D.; Wai, K.N.; Parijat, K.; Sanggu, K.; Reginald, B.H.T. Formulation design, preparation and physicochemical characterizations of solid lipid nanoparticles containing a hydrophobic drug: Effects of process variables. Colloids Surfaces B Biointerfaces 2011, 88, 483-489.

54. Dinarello, C. Impact of basic research on tomorrow's medicine. Proinflammatory cytokines. CHEST J. 2000, 118, 503-508. [CrossRef]

55. De Groot, A.S.; Scott, D.W. Immunogenicity of protein therapeutics. Trends Immunol. 2007, 28, 482-490. [CrossRef] [PubMed]

56. Zolnik, B.S.; González, F.Á.; Sadrieh, N.; Dobrovolskaia, M. Minireview: Nanoparticles and the immune system. Endocrinology 2010, 151, 458-465. [CrossRef] [PubMed]

57. Veranth, J.M.; Kaser, E.G.; Veranth, M.M.; Koch, M.; Yost, G.S. Cytokine responses of human lung cells (BEAS-2B) treated with micron-sized and nanoparticles of metal oxides compared to soil dusts. Part Fibre Toxicol. 2007, 4. [CrossRef] [PubMed]

58. Lewinski, N.; Colvin, V.; Drezek, R. Cytotoxicity of nanopartides. Small 2008, 4, 26-49. [CrossRef] [PubMed]

59. Fiona, R.; Chapman, J.; Sullivan, T. Nanoparticles in Anti-Microbial Materials: Use and Characterisation; Royal Society of Chemistry: Cambridge, UK, 2012. [CrossRef]

60. Jun, Y.; Kim, H.; Song, M.; Lim, J.; Lee, D.; Han, K.; Choi, J. In vitro effects of ciprofloxacin and roxithromycin on apoptosis of Jurkat T lymphocytes. Am. Soc. Microbiol. 2003, 47, 1161-1164. [CrossRef]

61. Dalhoff, A; Shalit, I. Immunomodulatory effects of quinolones. Lancet Infect. Dis. 2003, 3, 359-371.

62. Garcia-Käufer, M.; Haddad, T.; Bergheim, M.; Gminski, R.; Gupta, P.; Mathur, N. Genotoxic effect of ciprofloxacin during photolytic decomposition monitored by the in vitro micronucleus test (MNvit) in HepG2 cells. Environ. Sci. Pollut. Res. 2012, 19, 1719-1727. [CrossRef] [PubMed]

63. Gürbay, A.; Garrel, C.; Osman, M.; Richard, M.J.; Favier, A.; Hincal, F. Cytotoxicity in ciprofloxacin-treated human fibroblast cells and protection by vitamin E. Hum. Exp. Toxicol. 2002, 21, 635-641. [CrossRef] [PubMed]

64. Lawrence, J.W.; Claire, D.C.; Weissig, V.; Rowe, T.C. Delayed cytotoxicity and cleavage of mitochondrial DNA in ciprofloxacin-treated mammalian cells. Mol. Pharm. 1996, 50, 1178-1188.

65. Kean, T.; Roth, S.; Maya, T. Trimethylated chitosans as non-viral gene delivery vectors: Cytotoxicity and transfection efficiency gene delivery. J. Control. Release 2005, 103, 643-653. [CrossRef] [PubMed]

66. Battal, D.; Celik, A.; Güler, G.; Aktaş, A.; Yildirimcan, S.; Ocakoglu, K.; Çömelekoğlu, Ü. SiO 2 nanoparticule-induced size-dependent genotoxicity-An in vitro study using sister chromatid exchange, micronucleus and comet assay. Drug Chem. Toxicol. 2015, 38, 196-204. [CrossRef] [PubMed]

67. Hernández-Ortiz, M.; Acosta-Torres, L.S.; Hernández-Padrón, G.; Mendieta, A.I.; Bernal, R.; Cruz-Vázquez, C. Biocompatibility of crystalline opal nanoparticles. Biomed. Eng. Online 2012, 11. [CrossRef] [PubMed]

68. Ruparelia, J.P.; Chatterjee, A.K.; Duttagupta, S.P.; Mukherji, S. Strain specificity in antimicrobial activity of silver and copper nanoparticles. Acta Biomater. 2008, 4, 707-716. [CrossRef] [PubMed]

69. Zhao, L.; Zhu, B.; Jia, Y.; Hou, W.; Su, C. Preparation of biocompatible carboxymethyl chitosan nanoparticles for delivery of antibiotic drug. BioMed Res. Int. 2013, 2013, 1-8. [CrossRef] [PubMed]

70. Abed, N.; Couvreur, P. Nanocarriers for antibiotics: A promising solution to treat intracellular bacterial infections. Int. J. Antimicrob. Agents 2014, 43, 485-496. [CrossRef] [PubMed]

71. Shegokar, R.; Müller, R.H. Nanocrystals: Industrially feasible multifunctional formulation technology for poorly soluble actives. Int. J. Pharm. 2010, 399, 129-139. [CrossRef] [PubMed]

72. Mitri, K.; Shegokar, R.; Gohla, S.; Anselmi, C.; Müller, R.H. Lutein nanocrystals as antioxidant formulation for oral and dermal delivery. Int. J. Pharm. 2011, 420, 141-146. [CrossRef] [PubMed]

73. Georgieva, A.; Bogdanov, B.; Stefanov, Z.; Koleva, D. Microemulsion water-in-oil (W/O)—Microreactor for synthesis of ultrafine carbonate nanostructures. Univ. Ruse Union Sci.-Ruse 2011, 50, 34-38. 
74. Zaki, N.M.; Hafez, M.M. Enhanced antibacterial effect of ceftriaxone sodium-loaded chitosan nanoparticles against intracellular Salmonella typhimurium. AAPS Pharm. Sci. Technol. 2012, 13, 411-421. [CrossRef] [PubMed]

75. Yaod, Z.R.G.W.; Sheng, B.; Yao, D.; Wei, Y.H. Pharmacopoeia of the People's Republic of China/compiled by the State Pharmacopoeia Commission of the People's Republic of China; Chemical Industry Press: Beijing, China, 2000.

76. Islam, K.N.; Zuki, A.Z.; Ali, M.E.; Zobir, M.; Hussein, B.; Noordin, M.M. Facile synthesis of calcium carbonate nanoparticles from cockle shells. J. Nanomater. 2012, 2012, 1-5. [CrossRef]

77. Cockerill, F.R.; Wikler, M.A.; Alder, J.; Dudley, M.N.; Eliopoulos, G.M.; Ferraro, M.J.; Hardy, D.J.; Hecht, D.W.; Hindler, J.A.; Patel, J.B.; et al. Methods for Dilution Antimicrobial Susceptibility Tests for Bacteria that Grow Aerobically, Approved Standard-Ninth Edition; Clinical and Laboratory Standards Institute: Wayne, PA, USA, 2012.

78. Roy, S.A. Effect of nano-titanium dioxide with different antibiotics against methicillin-resistants Staphylococcus aureus. J. Biomater. Nanobiotechnol. 2010, 1, 37-41. [CrossRef]

(C) 2016 by the authors; licensee MDPI, Basel, Switzerland. This article is an open access article distributed under the terms and conditions of the Creative Commons Attribution (CC-BY) license (http://creativecommons.org/licenses/by/4.0/). 